\title{
Pengaruh Penuaan Aspal Pada Karakteristik Compuran Beton Aspal Lapis Aus AC - WC
}

\author{
Mashuria dan R. Rahman ${ }^{\mathrm{a} *}$ \\ a Jurusan Teknik Sipil, Fakultas Teknik Universitas Tadulako, Palu \\ *Corresponding author's e-mail: mashuri 70mt@yahoo.co.id
}

Received: 3 August 2020; revised: 18 August 2020; accepted: 19 August 2020

\begin{abstract}
The aging process of asphalt in the pavement layers of asphalt concrete road occurs when mixing in the Asphalt Mixing Plant and during the road service period. The asphalt aging process when mixing is called short-term aging and aging during the road service period is called long-term aging. AC - WC mixture is a wear layer and it is on the top layer of the surface which allows characteristics change that are influenced by several environmental factors (air, temperature and sunlight). This study aims to know the effect of asphalt aging on the characteristics of AC - WC mixture with Marshall method on some asphalt content that are 4.5\%, 5.0\%, 5.5\%, 6.0\%, 6, 5\% and 7.0\%. For testing on short-term aging (Short - Term Oven Aging, STOA) is by testing the mixture specimen AC - WC at $135 \mathrm{o} C$ before solidified for 4 hours and for long-term aging (Long - Term Oven Aging, LTOA) was carried out by testing the mixture specimen AC WC at $850 \mathrm{C}$ for 2 - 5 days. The results of this study found that asphalt aging had an effect on the characteristics of AC - WC mixture. Values of density, VFB, stability, flow tend to decrease with age. While VIM and VMA values tend to increase with age. Aging caused the mixture to became more rigid.
\end{abstract}

Keywords: aging, STOA, LTOA, AC - WC, Marshall.

\begin{abstract}
Abstrak: Proses penuaan aspal pada lapis perkerasaan jalan beton aspal terjadi saat pencampuran di $A M P$ dan saat masa pelayanan jalan Proses penuaan aspal saat pencampuran disebut penuaan jangka pendek dan penuaan saat masa pelayanan jalan disebut penuaan jan gka panjang. Campuran $A C-W C$ merupakan lapis aus dan berada di lapis permukaan yang paling atas yang memungkinkan terjadinya perubahan karakteristik yang dipengaruhi oleh beberapa faktor lingkungan (udara, temperatur dan sinar matahari). Penelitian ini bertujuan untuk mengetahui pengaruh penuaan aspal pada karakteristik campuran $A C$ - WC dengan metode Marshall pada beberapa kadar aspal yaitu $4,5 \%, 5,0 \%, 5,5 \%, 6,0 \%, 6,5 \%$ dan 7,0\%. Untuk pengujian pada penuaan jangka pendek (Short - Term Oven Aging, STOA) adalah dengan pengovenan benda uji campuran $A C-W C$ pada suhu $135^{\circ} \mathrm{C}$ sebelum dipadatkan selama 4 jam dan untuk penuaan jangka panjang (Long - Term Oven Aging, LTOA) dilakukan pengovenan benda uji campuran $A C-W C$ pada suhu $85^{\circ} \mathrm{C}$ selama 2 - 5 hari. Hasil penelitian ini mendapatkan bahwa penuaan aspal memberi pengaruh pada karakteristik campuran $A C-W C$. Nilai kepadatan, VFB, stabilitas, flow cenderung turun seiring lamanya umur penuaan. Sementara nilai VIM dan VMA cenderung meningkat seiring lamanya umur penuaan. penuaan mengakibatkan campuran menjadi lebih kaku.
\end{abstract}

Kata kunci: penuaan, STOA, LTOA, AC-WC, Marshall.

\section{Pendahuluan}

Pada perkerasan jalan, campuran $A C-W C$ digunakan untuk lapis permukaan paling atas (lapis aus) sehingga sering kali mengalami kerusakan atau penurunan kekuatan.Salah satu penyebab kerusakan dan penurunan kekuatan pada perkerasan lentur adalah terjadinya proses penuaan (aging) aspal serta pengaruh yang diakibatkan oleh perubahan temperatur. Penuaan aspal yang dipengaruhi oleh temperatur disebabkan oleh dua faktor utama, yaitu penguapan fraksi minyak ringan yang terkandung dalam aspal dan oksidasi penuaan jangka pendek, Short-Term Oven Aging (STOA) dan oksidasi yang progresif penuaan jangka panjang, Long-Term Oven Aging (LTOA) [1-7). Proses terjadinya penuaan (aging) pada campuran beton aspal sangat tergantung kepada hasil pencampuran dan pemadatan yang dilakukan. Proses pengujian penuaan jangka pendek (Short Term Oven Aging, STOA), dilakukan pengovenan pada suhu $135^{\circ} \mathrm{C}$ selama 4 jam sebelum dilakukan pemadatan. Simulasi STOA dilakukan untuk mengetahui penuaan campuran aspal pada saat proses pembuatan campuran aspal di unit pencampuran aspal $(A M P)$, selama pengangkutan dan penghamparan di lapangan. Sedangkan prosedur pengujian penuaan jangka panjang (Long Term Oven Aging, LTOA) dilakukan pengovenan pada suhu $85^{\circ} \mathrm{C}$ selama 48 jam dan 120 jam setelah dilakukan pemadatan. Simulasi LTOA ini dilakukan untuk mengetahui penuaan campuran aspal selama masa pelayanan. Pengujian pada suhu $85^{\circ} \mathrm{C}$ selama 48 jam mewakili umur campuran selama 5 tahun di lapangan dan pengujian pada suhu $85^{\circ} \mathrm{C}$ selama 120 jam mewakili umur campuran selama 10 tahun di lapangan [8-11].

\subsection{Lapis Aspal Beton (AC-WC)}

Laston (Lapisan Aspal Beton), adalah beton aspal bergradasi menerus yang umum digunakan untuk jalanjalan dengan beban lalu lintas berat. Laston sebagai lapis aus (Asphalt Concrete Wearing Course, $A C-W C$ ) merupakan lapisan paling atas dari laston yang mengalami kontak langsung dengan kendaraan yang melintas di atasnya. AC - WC mempunyai tekstur yang lebih halus dibandingkan dengan laston lapis antara (AC-BC). 
Disamping sebagai pendukung beban lalu lintas, lapisan ini mempunyai fungsi utama sebagai pelindung konstruksi di bawahnya dari kerusakan akibat pengaruh air dan cuaca, sebagai lapisan aus dan menyediakan permukaan jalan yang rata dan tidak licin.

\subsection{Persyaratan Material Campuran $A C-W C$}

\section{a) Agregat Kasar}

Fraksi agragat kasar untuk rancangan campuran adalah yang tertahan ayakan No.8 (2,36 $\mathrm{mm})$ yang dilakukan secara basah dan harus bersih, keras, awet, dan bebas dari lempung atau bahan yang tidak dikehendaki lainnya dan memenuhi ketentuan (Tabel 1) [12-13].

Tabel 1. Ketentuan agregat kasar

\begin{tabular}{|c|c|c|c|c|}
\hline \multicolumn{3}{|c|}{ Pengujian } & $\begin{array}{c}\text { Metode } \\
\text { Pengujian }\end{array}$ & Spesifikasi \\
\hline \multirow{2}{*}{\multicolumn{2}{|c|}{$\begin{array}{c}\text { Kekekalan bentuk } \\
\text { agregat terhadap } \\
\text { larutan }\end{array}$}} & $\begin{array}{c}\text { Natrium } \\
\text { Sulfat }\end{array}$ & SNI & $\begin{array}{l}\text { Maks } \\
12 \%\end{array}$ \\
\hline & & $\begin{array}{l}\text { Magnesium } \\
\text { Sulfat }\end{array}$ & 3407:2008 & $\begin{array}{l}\text { Maks } \\
18 \%\end{array}$ \\
\hline \multirow{4}{*}{$\begin{array}{l}\text { Abrasi } \\
\text { dengan } \\
\text { Mesin } \\
\text { Los } \\
\text { Aggeles }\end{array}$} & \multirow{2}{*}{$\begin{array}{l}\text { Camp. AC } \\
\text { modifikasi }\end{array}$} & 100 putaran & \multirow{4}{*}{$\begin{array}{l}\text { SNI } \\
2417: 2008\end{array}$} & Maks 6\% \\
\hline & & 500 putaran & & \\
\hline & \multirow{2}{*}{$\begin{array}{l}\text { Campuran } \\
\text { aspal } \\
\text { gradasi } \\
\text { lainnya }\end{array}$} & 100 putaran & & Maks $8 \%$ \\
\hline & & 500 putaran & & $\begin{array}{l}\text { Maks } \\
40 \%\end{array}$ \\
\hline \multicolumn{3}{|c|}{ Kelekatan agregat terhadap aspal } & $\begin{array}{l}\text { SNI } \\
\text { 2439:2011 }\end{array}$ & $\begin{array}{l}\text { Maks } \\
95 \%\end{array}$ \\
\hline \multicolumn{3}{|c|}{ Butir pecah pada agregat aspal } & $\begin{array}{l}\text { SNI } \\
7619: 2012\end{array}$ & $95 / 90 *)$ \\
\hline \multicolumn{3}{|c|}{ Partikel pipih dan lonjong } & $\begin{array}{l}\text { ASTM } \\
\text { D4791 } \\
\text { P1:5 }\end{array}$ & $\begin{array}{l}\text { Maks } \\
10 \%\end{array}$ \\
\hline \multicolumn{3}{|c|}{ Material lolos ayakan No. 200} & $\begin{array}{l}\text { SNI 08- } \\
41-42- \\
1996\end{array}$ & Maks $2 \%$ \\
\hline
\end{tabular}

*) 95/90 menunjukan bahwa 95\% agregat kasar mempunyai muka bidang pecah satu atau lebih dan $90 \%$ agregat kasar mempunyai muka bidang pecah dua atau lebih. b) Agregat Halus

Agregat halus dari sumber mana pun, harus terdiri dari pasir atau hasil ayakan batu pecah yang terdiri dari bahan yang lolos ayakan No.8 (4,75 mm). Agregat halus harus merupakan bahan yang bersih, keras, dan bebas dari lempung atau bahan yang tidak dikehendaki lainnya (Tabel 2).

Tabel 2. Ketentuan agregat halus

\begin{tabular}{lll}
\hline Pengujian & $\begin{array}{l}\text { Metode } \\
\text { Pengujian }\end{array}$ & Spesifikasi \\
\hline Nilai setara pasir & SNI 03-4428- & Maks 60\% \\
& 1997 & \\
\hline Angularitas dengan uji & SNI 03-6877- & Min 45\% \\
kadar rongga & 2002 & \\
\hline $\begin{array}{l}\text { Gumpalan lempung dan } \\
\text { butir-butir mudah pecah }\end{array}$ & SNI 03-4141- & Maks 1\% \\
\hline Agregat lolos ayakan No. & SNI ASTM & Maks 10\% \\
200 & C1 17-2013 & \\
\hline
\end{tabular}

c) Bahan Pengisi

Bahan pengisi yang ditambahkan (filler added) terdiri atas debu batu kapur (limestone dust, Calcium Carbonate $\mathrm{CaCO}_{3}$ ), atau debu kapur padam yang sesuai dengan AASHTO M303-89 (2006), semen atau mineral yang berasal dari asbuton. Bahan pengisi yang ditambahkan harus kering dan bebas dari gumpalangumpalan dan bila di uji dengapengayakan harus mengandung bahan yang lolos ayakan No.200 (75 micron) tidak kurang dari $75 \%$ terhadap beratnya kecuali untuk mineral asbuton (Tabel 3) [12-13].

Tabel 3. Persyaratan mineral filler

\begin{tabular}{ccc}
\hline \multirow{3}{*}{$\begin{array}{c}\text { Sifat } \\
\text { Umum }\end{array}$} & Kadar Air & Max 1\% \\
\cline { 2 - 3 } & $\begin{array}{c}\text { Gumpalan } \\
\text { Partikel }\end{array}$ & Tidak Ada \\
\cline { 2 - 3 } & $\begin{array}{c}\text { Bukaan Saringan } \\
(\mathbf{m m})\end{array}$ & $\begin{array}{c}\text { \% Lolos } \\
\text { Saringan }\end{array}$ \\
\hline \multirow{3}{*}{ Gradasi } & 0,6 & 100 \\
\cline { 2 - 3 } & 0,13 & $90-100$ \\
\cline { 2 - 3 } & 0,074 & $70-100$ \\
\hline
\end{tabular}

Tabel 4. Ketentuan-ketentuan aspal kasar

\begin{tabular}{|c|c|c|c|c|c|}
\hline \multirow{3}{*}{ No } & \multirow{3}{*}{ Jenis Pengujian } & \multirow{3}{*}{ Metode Pengujian } & \multirow{3}{*}{$\begin{array}{l}\text { Tipe I } \\
\text { Aspal Pen. } \\
60-70\end{array}$} & \multicolumn{2}{|c|}{ Tipe II Aspal yang dimodifikasi } \\
\hline & & & & $\mathbf{A}$ & B \\
\hline & & & & $\begin{array}{l}\text { Asbuton } \\
\text { diproses }\end{array}$ & $\begin{array}{c}\text { Elastomer } \\
\text { Sintetis }\end{array}$ \\
\hline 1 & Penetrasi pada $25^{\circ} \mathrm{C}(0,1 \mathrm{~mm})$ & SNI 06-2456-1991 & $60-70$ & Min. 50 & Min. 40 \\
\hline 2 & Viskositas dinamis $60^{\circ} \mathrm{C}(\mathrm{Pa} . \mathrm{s})$ & SNI 06-6441-2000 & $160-240$ & $240-360$ & $320-480$ \\
\hline 3 & Viskositas kinematis $60^{\circ} \mathrm{C}(\mathrm{cSt})$ & SNI 06-6441-2000 & $\geq 300$ & $385-480$ & $\leq 3000$ \\
\hline 4 & Titik lembek $\left({ }^{\circ} \mathrm{C}\right)$ & SNI 2434:2011 & $\geq 48$ & $\geq 53$ & $\geq 54$ \\
\hline 5 & Daktilitas pada $25^{\circ} \mathrm{C}(\mathrm{cm})$ & SNI 2434:2011 & $\geq 100$ & $\geq 100$ & $\geq 100$ \\
\hline 6 & Titik nyala $\left({ }^{\circ} \mathrm{C}\right)$ & SNI 2434:2011 & $\geq 232$ & $\geq 232$ & $\geq 232$ \\
\hline 7 & Kelarutan $(\%)$ & AASHTO T44-03 & $\geq 99$ & $\geq 99^{(1)}$ & $\geq 99$ \\
\hline 8 & Berat jenis & SNI 2434:2011 & $\geq 1.0$ & $\geq 1.0$ & $\geq 1.0$ \\
\hline 9 & Stabilitas penyimpanan $\left({ }^{\circ} \mathrm{C}\right)$ & ASTM D5976 & - & $\leq 2.2$ & $\leq 2.2$ \\
\hline 10 & Partkel lebih halus 150 micron (\%) & & & Min $95^{(1)}$ & - \\
\hline \multicolumn{6}{|c|}{$\begin{array}{l}\text { Pengujian Residu Hasil TFOT (SNI 06-2441-1991) atau RTFOT (SNI 06-6835-2002) } \\
\end{array}$} \\
\hline 11 & Berat yang hilang $(\%)$ & SNI 06-2441-2000 & $\leq 0.8$ & $\leq 0.8$ & $\leq 0.8$ \\
\hline 12 & Viskositas dinamis $60^{\circ} \mathrm{C}(\mathrm{Pa} . \mathrm{s})$ & SNI 06-2441-2000 & $\leq 800$ & $\leq 1200$ & $\leq 1600$ \\
\hline 13 & Penetrasi pada $25^{\circ} \mathrm{C}(\%)$ & SNI 06-2456-1991 & $\geq 54$ & $\geq 54$ & $\geq 54$ \\
\hline 14 & Daktilitas pada $25^{\circ} \mathrm{C}(\mathrm{cm})$ & SNI 2432:2011 & $\geq 100$ & $\geq 50$ & $\geq 25$ \\
\hline 15 & Elastisitas setelah pengembalian & AASHTO T301-98 & - & - & $\geq 60$ \\
\hline
\end{tabular}


d) Aspal

Aspal didefinisikan sebagai material berwarna hitam atau coklat tua, pada temperatur ruang berbentuk padat sampai agak padat.Jika dipanaskan pada suatu temperatur tertentu aspal dapat menjadi lunak/cair sehingga dapat membungkus partikel agregat pada waktu pembuatan aspal beton atau dapat masuk ke dalam pori-pori yang pada penyemprotan /penyiraman pada perkerasan macadam atau peleburan. Jika temperatur mulai turun, aspal akan mengeras dan mengikat agregat pada tempatnya (sifat termoplastis). Sebagai salah satu konstruksi perkerasan lentur, aspal merupakan komponen kecil, umumnya kadar aspal yang digunakan 4\%-10\% berdasarkan berat atau 5\%-10\% berdasarkan volume (Tabel 4) [12-13].

Catatan :

1) Hasil pengujian adalah untuk bahan pengikat (bitumen) yang diektraksi dengan menggunakan metoda SNI 2490:2008. Sedangkan untuk pengujian kelarutan dan gradsi mineral dilaksanakan pada seluruh bahan pengikat termasuk kandungan meneralnya.

2) Pabrik pembuat bahan pengikat Tipe II dapat mengajukan metoda pengujian alternatif untuk pengunjian penetrasi, titik lembek atau standar lainnya,

3) Viskositas diuji juga pada temperatur $100^{\circ} \mathrm{C}$ atau $160^{\circ} \mathrm{C}$ untuk tipe I, untuk tipe II, pada temperatur $100^{\circ} \mathrm{C}$ dan $170^{\circ} \mathrm{C}$

4) Jika untuk pengujian viskositas tidak dilakukan sesuai dengan AASHTO T201-03 maka hasil pengujian harus dikonversikan ke cSt.

\subsection{Karakteristik Campuran}

Menurut Sukirman (2003) lapis aspal beton (laston) digunakan untuk jalan - jalan dengan beban lalu lintas berat, laston juga dikenal dengan nama AC (Asphalt Concrete). Ada tujuh karakteristik campuran yang harus dimiliki oleh aspal beton sebagai berikut [12-13] :

1) Stabilitas

2) Durabilitas (keawetan)

3) Fleksibilitas (kelenturan)

4) Fatiqueresistance (ketahanan kelelehan)

5) Skid Resistance (kekesatan terhadap slip)

6) Impermeable (kedap air)

7) Workability (kemudahan pelaksanaan)

\subsection{Rancangan Campuran $A C-W C$}

Tujuan dari perencanaan campuran (mix design) untuk memperoleh nilai kadar aspal optimum (KAO) untuk suatu gradasi agregat sehingga menghasilkan suatu campuran beton aspal yang memenuhi spesifikasi yang telah ditetapkan. Bahan - bahan yang akan digunakan dalam penelitian ini dipilih agar dapat memenuhi spesifikasi campuran $A C-W C$. Penentuan komposisi campuran antar agregat kasar, agregat halus dan bahan pengisi dimaksudkan untuk mendapatkan suatu komposisi campuran yang memenuhi syarat gradasi sehingga diperoleh suatu lapis permukaan dimana ikatan antar butir - butir agregat baik atau saling mengunci.
Pada rancangan campuran $\mathrm{AC}-\mathrm{WC}$, gradasi agregat gabungan merupakan hal yang paling penting. Gradasi agregat gabungan harus mempunyai jarak terhadap batas batas toleransi (Tabel 5).

Tabel 5. Gradasi agregat gabungan untuk campuran laston

\begin{tabular}{cccc}
\hline \multirow{2}{*}{$\begin{array}{c}\text { Ukuran } \\
\text { Ayakan } \\
(\mathbf{m m})\end{array}$} & \multicolumn{3}{c}{$\begin{array}{c}\text { \% Berat Yang Lolos Terhadap Total } \\
\text { Agregat dalam Campuran }\end{array}$} \\
\cline { 2 - 4 } & \multicolumn{3}{c}{ Laston (AC) } \\
\cline { 2 - 4 } & WC & BC & Base \\
\hline 37,5 & & & 100 \\
\hline 25 & & & $90-100$ \\
\hline 19 & 100 & $90-100$ & $76-90$ \\
\hline 12,5 & $90-100$ & $75-90$ & $60-78$ \\
\hline 9,5 & $77-90$ & $66-82$ & $52-71$ \\
\hline 4,75 & $53-69$ & $46-64$ & $35-54$ \\
\hline 2,36 & $33-53$ & $30-49$ & $23-41$ \\
\hline 1,18 & $21-40$ & $18-38$ & $13-30$ \\
\hline 0,600 & $14-30$ & $12-28$ & $10-22$ \\
\hline 0,300 & $9-22$ & $7-20$ & $6-15$ \\
\hline 0,150 & $6-15$ & $5-13$ & $4-10$ \\
\hline 0,075 & $4-9$ & $4-8$ & $3-7$ \\
\hline
\end{tabular}

\subsection{Komposisi Umum Campuran}

Campuran untuk lapis beton terdiri atas kombinasi agregat kasar, agregat halus, bahan pengisi (bila diperlukan) dan aspal. Bahan - bahan campuran ini terlebih dahulu harus direncanakan sehingga setelah dikerjakan dapat diperoleh perkerasan aspal yang memenuhi kriteria karakteristik campuran beton aspal.

Penentuan proporsi masing - masing fraksi agregat dilakukan dengan gradasi by sieve. Metode ini dilakukan dengan cara penimbangan berdasarkan komposisi untuk masing - masing ukuran saringan.

Tabel 6. Ketentuan Sifat-sifat campuran lapis aspal beton (LASTON)

\begin{tabular}{llcc}
\hline \multirow{2}{*}{ Sifat-Sifat Campuran } & \multicolumn{2}{c}{ LASTON } \\
\cline { 2 - 3 } & \multicolumn{2}{c}{ Halus } & Kasar \\
\cline { 2 - 3 } & Min & 5,1 & 4,3 \\
\hline Kadar aspal afektif (\%) & Maks & 1,2 \\
\hline Penyerapan aspal (\%) & Min & 3,5 \\
\hline Jumlah tumbukan perbidang & & 5,0 \\
\hline $\begin{array}{l}\text { Rongga dalam campuran } \\
\text { (\%) }\end{array}$ & Maks & 15 \\
\hline & Min & 65 \\
\hline Rongga dalam agregat (\%) & Min & 800 \\
\hline Rongga terisi aspal (\%) & Min & 3,0 \\
\hline Stabilitas Marshall (kg) & Min & 250 \\
\hline Pelelehan (mm) & Min & 90 \\
\hline Marshall Quotient & Min & \\
\hline $\begin{array}{l}\text { Stabilitas Marshall sisa } \\
\text { setelah perendaman 24 jam, } \\
\text { 60 C(5) }\end{array}$ & & 2,5 \\
\hline $\begin{array}{l}\text { Rongga dalam campuran } \\
\text { pada kepadatan membal } \\
\text { (\%) }\end{array}$ & Min \\
\hline
\end{tabular}

\subsection{Spesifikasi Campuran $A C-W C$}

Agar dapat memenuhi kualitas dan keseragaman jenis lapisan yang telah dipilih dalam perencanaan, perlu ditentukan spesifikasi campuran yang menjadi dasar 
pelaksanaan dilapangan (Tabel 6). Spesifikasi campuran berbeda- eda dipengaruhi oleh :

1) Perencanaan tebal perkerasan, yang dipengaruhi oleh pemilihan metode penentuan tebal perkerasaan.

2) Ekspresi gradasi agregat, yang dinyatakan dengan nomor saringan yang umumnya digunakan dalam spesifikasi.

3) Kadar aspal, yang umumnya dinyatakan dalam persen terhadap berat campuran seluruhnya.

4) Komposisi dari campuran yang diinginkan, dinyatakan dalam nilai stabilitas, flow, VIM, VMA, VFB dan tebal film aspal.

5) Metode rencana campuran yang digunakan.

\subsection{Proses Penuaan Aspal}

Menurut Belt (1994, dalam Supriadi, 2018), penuaan aspal adalah suatu parameter yang baik untuk mengetahui durabilitas campuran beraspal. Penuaan aspal tersebut disebabkan oleh 2 faktor utama, yaitu penguapan fraksi minyak ringan yang terkandung dalam aspal dan oksidasi (penuaan jangka pendek, Short-Term Aging), serta oksidasi yang progresif (penuaan jangka panjang, Long-Term Aging) [14].

Oksidasi merupakan suatu faktor penting yang menentukan kecepatan penuaan. Kecepatan penuaan jangka panjang semata - mata disebabkan oleh oksidasi kecepatan oksidasi yang terjadi sangat dipengaruhi oleh rongga udara yang terkandung dalam campuran dan lingkaran dimana campuran ini dihamparkan. Dari kedua hal tersebut, Glenn et al. (1981, dalam Damraeni, 2009) mengatakan bahwa lingkungan lebih memberikan pengaruh pada penuaan aspal dibandingkan dengan rongga udara dalam campuran atau porositas agregat yang digunakan [8]. Pendapat yang sama juga dinyatakan oleh Yau et al. (1985, dalam Irfan, 2012) yang mengatakan bahwa oksidasi adalah penyebab utama pengerasan aspal yang merupakan hasil interaksi antara aspal dengan lingkungan [9].

a. Short-Term Oven Aging (STOA)

Short - Term Oven Aging (STOA) merupakan metode pengujian yang dikembangkan oleh strategic highway research program (SHRP) project A-003 A. Pada metode pengujian STOA dilakukan proses pemanasan oven di laboratorium selama 4 jam pada campuran lepas (loose mixture) panas dengan temperatur $135^{\circ} \mathrm{C}$. pengovenan ini dimaksudkan untuk mensimulasi proses penuaan pada campuran aspal selama proses konstruksi, pencampuran, pengangkutan, penghamparan dan pemadatan.

b. Long - Term Oven Aging (LTOA)

Long - Term Oven Aging (LTOA) merupakan metode pengujian yang dikembangkan oleh strategic highway research program (SHRP) project A - 003 A. Pada metode pengujian LTOA dilakukan proses pemanasan oven di Laboratorium selama 2 hari dan 5 hari pada temperatur $85^{\circ} \mathrm{C}$, pada spesimen padat. Untuk proses pemanasan oven selama 2 hari dimaksudkan untuk mensimulasikan keadaan proses penuaan pada campuran aspal selama 5 tahun umur pelayanan, sedangkan pada proses pemanasan oven selama 5 hari dimaksudkan untuk mensimulasikan keadaan proses penuaan pada campuran aspal selama 10 tahun layanan.

\section{Metode Penelitian}

Metode penelitian yang akan digunakan untuk mengarahkan penelitian agar mencapai tujuan yang diinginkan, yakni mengetahui pengaruh penuaan aspal pada karakteristik campuran aspal beton lapis aus (AC-WC). Metode penelitian akan memberikan informasi seputar objek penelitian, serta langkah - langkah terarah dalam perencanaan dan pelaksanaan penelitian untuk mencapai tujuan. Sehingga dengan tercapainya tujuan maka akan menjawab rumusan masalah yang ada

\subsection{Jenis Penelitian}

Penelitian ini merupakan penelitian experimental, karena penelitian bersifat laboratories. Penelitian eksperimen adalah suatu jenis penelitian yang digunakan untuk mencari pengaruh perlakuan tertentu terhadap yang lain dalam kondisi yang terkendalikan (Sugiyono, 2017). Penelitian ini juga menggunakan pendekatan kuantitatif yang berdasarkan pada filsafat positivisme, digunakan untuk meneliti pada sampel tertentu, pengumpulan data menggunakan instrument penelitian, analisis data bersifat kuantitatif/statistik sehingga penelitian eksperimen kuantitatif adalah penelitian dengan menggumpulkan data yang diperoleh dari benda uji yang dibuat oleh peneliti di laboratorium, kemudian nilai yang diperoleh dari seluruh benda uji dianalisis sesuai dengan metode statistik yang digunakan $[11,15]$.

\subsection{Prosedur Penelitian}

Prosedur penelitian menggunakan langkah-langkah yang disusun untuk memberikan kemudahan dalam melaksanakan penelitian sehingga lebih efisien dan efektif dalam mencapai tujuan penelitian yang ingin dicapai.

a. Bahan Penelitian

Bahan Penelitian terdiri dari agregat yang berasal dari stone crusher Sungai Bahomante yang terletak di Kecamatan Bungku Tengah Kabupaten Morowali Provinsi Sulawesi Tengah dan aspal Pen 60/70 produksi pertamina.

b. Pemeriksaan Material

Pemeriksaan agregat kasar meliputi berat jenis dan abrasi, pemeriksaan agregat halus dan filler meliputi berat jenis. Sedangkan pemeriksaan aspal meliputi uji penetrasi, berat jenis, titik lembek, kehilangan berat minyak dan aspal, daktilitas dan viskositas.

c. Desain Gradasi Campuran

Pada Penelitian ini dalam menentukan komposisi gradasi campuran menggunakan gradasi by sieve.

d. Pembuatan Benda Uji

Pembuatan benda uji campuran AC - WC menggunakan perkiraan kadar aspal optimum (PKAO) pada kondisi standar dan kondisi penuaan (STOA, LTOA 5 tahun dan LTOA 10 tahun). Seperti yang telah dilakukan oleh Irfan, (2012).

e. Pengujian Benda Uji

Pengujiaan benda uji menggunakan alat Marshall dan Uji Volumetrik. 
REKOnSTRUKSI TADULAKO: Civil Engineering Journal on Research and Development, Vol. 1(2), September 2020

f. Analisa dan Pembahasan

Penuaan aspal seperti STOA, LTOA 5 tahun dan LTOA 10 tahun sebagai variabel bebas sementara data karakteristik Marshall seperti Stabilitas, flow dan MQ serta uji volumetrik seperti kepadatan, VIM, VMA dan VFB sebagai variabel terikat

\subsection{Lokasi Pengambilan Material}

Penelitian ini diawali dengan penyeleksian data hujan dan debit harian maksimum yang mewakili masing-masing tahun. Analisis frekuensi diterapkan untuk terhahadap kedua jenis data tersebut menggunakan empat metode Pengambilan material penelitian ini yang terdiri dari fraksi 3/4", fraksi 5/8", fraksi 1/2", agregat halus dan filler (abu batu) diambil dari lokasi stone crusher di Bahomante. Aspal yang akan digunakan merupakan aspal yang tersedia di lokasi penelitian di Laboratorium Transportasi dan Jalan Raya Fakultas Teknik Univ. Tadulako.

Bahan yang digunakan pada penelitian ini yaitu agregat kasar dengan fraksi $1 / 2 "$, fraksi $5 / 8$ ", dan abu batu diambil dari stone crusher Sungai Bahomante yang terletak di Kecamatan Bungku Tengah Kabupaten Morowali Provinsi Sulawesi Tengah (Gambar 1).

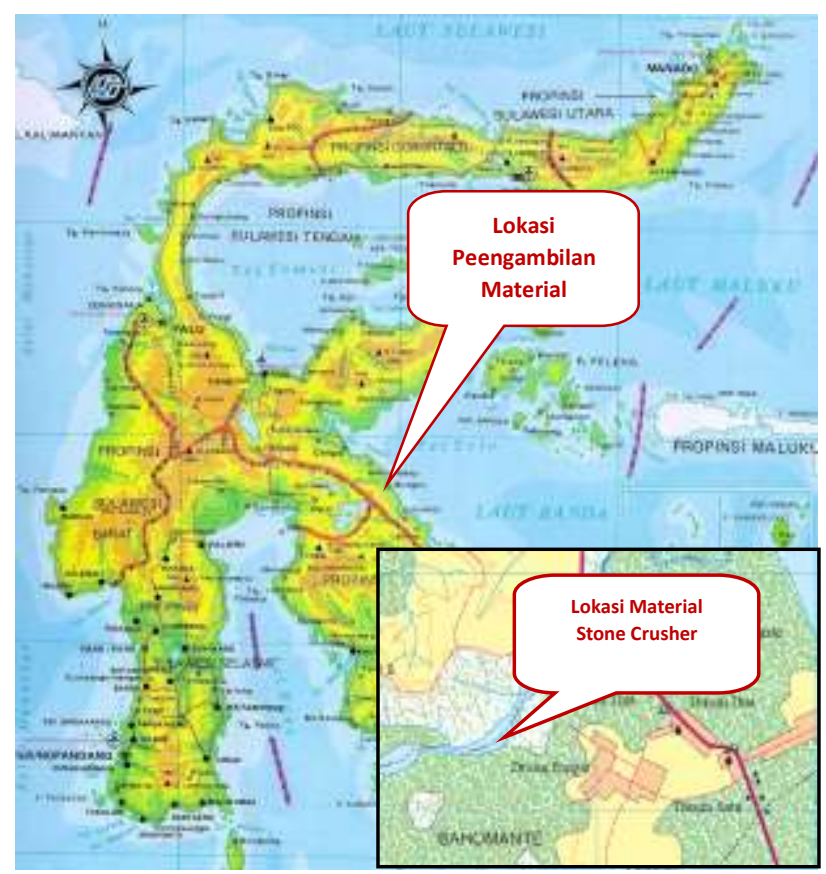

Gambar 1. Peta lokasi pengambilan agregat.

\section{Hasil dan Pembahasan}

\subsection{Hasil Pemeriksaan Material}

Hasil pemeriksaan material adalah seperti pada Tabel 7 , Tabel 8, Tabel 9 dan Tabel 10.

Tabel 7. Hasil pemeriksaan karakteristik filler (abu batu)

\begin{tabular}{clccc}
\hline No. & Pengujian & $\begin{array}{c}\text { Hasil } \\
\text { Pengujian }\end{array}$ & Spek. & Satuan \\
\hline 1 & $\begin{array}{l}\text { Analisa } \\
\text { saringan }\end{array}$ & - & - & - \\
\hline 2 & Berat jenis & 2,68 & $2,25-2,7$ & - \\
\hline
\end{tabular}

Tabel 8. Hasil pemeriksaan karakteristik agregat kasar fraksi $1 / 2$ "'

\begin{tabular}{clccc}
\hline No. & \multicolumn{1}{c}{ Pengujian } & $\begin{array}{c}\text { Hasil } \\
\text { Pengujian }\end{array}$ & Spek. & Sat. \\
\hline 1 & Analisa saringan & - & - & - \\
\hline 2 & Berat jenis & & & \\
\hline & a. Bj. bulk & 2,54 & & \\
\cline { 2 - 5 } & b. Bj. SSD & 2,60 & Min. 2,5 & \\
\cline { 2 - 5 } & c. Bj. apparent & 2,71 & & $\%$ \\
\cline { 2 - 5 } & $\begin{array}{l}\text { Penyerapan } \\
\text { agregat }\end{array}$ & 2,43 & Maks. 3 & $\%$ \\
\hline 3 & Abrasi & 29,86 & $\begin{array}{c}\text { Maks. } \\
40\end{array}$ & $\%$ \\
\hline
\end{tabular}

Tabel 9. Hasil pemeriksaan karakteristik agregat halus fraksi $5 / 8 "$

\begin{tabular}{clccc}
\hline No. & \multicolumn{1}{c}{ Pengujian } & $\begin{array}{c}\text { Hasil } \\
\text { Pengujian }\end{array}$ & Spek. & Sat. \\
\hline 1 & Analisa saringan & - & - & - \\
\hline 2 & Berat jenis & & & \\
\hline & d. Bj. bulk & 2,54 & & \\
\cline { 2 - 5 } & e. Bj. SSD & 2,601 & Min. 2,5 & \\
\cline { 2 - 5 } & f. Bj. apparent & 2,73 & & \\
\cline { 2 - 5 } & $\begin{array}{l}\text { Penyerapan } \\
\text { agregat }\end{array}$ & 2,67 & Maks. 3 & $\%$ \\
\hline
\end{tabular}

Tabel 10. Hasil Pemeriksaan Karakteristik Aspal Pen 60/70

\begin{tabular}{clccc}
\hline No. & \multicolumn{1}{c}{ Pengujian } & $\begin{array}{c}\text { Hasil } \\
\text { Pengujian }\end{array}$ & Spek. & Sat. \\
\hline 1 & $\begin{array}{l}\text { Penetrasi aspal } \\
\left(25^{\circ} \mathrm{C}, 5 \mathrm{dtk}\right)\end{array}$ & 67,6 & $60-70$ & $\mathrm{~mm}$ \\
\hline 2 & Titik lembek & 51,5 & $<48$ & ${ }^{\circ} \mathrm{C}$ \\
\hline 3 & Viskositas $135^{\circ} \mathrm{C}$ & 499,33 & $>3000$ & $\mathrm{Cst}$ \\
\hline 4 & BJ aspal $\left(25^{\circ} \mathrm{C}\right)$ & 1040 & Min. 1,0 & - \\
\hline 5 & $\begin{array}{l}\text { Daktilitas aspal } \\
\left(25^{\circ} \mathrm{C}\right)\end{array}$ & 107,5 & $\begin{array}{c}\text { Min. } \\
100\end{array}$ & $\mathrm{~cm}$ \\
\hline 5 & Kehilangan berat & 0,163 & Max. 1,0 & $\%$ \\
\hline
\end{tabular}

\subsection{Penentuan Komposisi Agregat Dalam Campuran}

Penentuan komposisi agregat menggunakan metode by sieve. Metode ini dilakukan dengan cara penimbangan berdasarkan komposisi untuk masing-masing ukuran saringan. Hasil penentuan komposisi agregat dengan metode gradasi by sieve dapat dilihat pada Tabel 11 .

Tabel 11. Penentuan Komposisi Agregat pada Campuran Hot Rolled Sheet (HRS)

\begin{tabular}{ccccccc}
\hline \multirow{2}{*}{$\begin{array}{c}\text { Sar. } \\
\text { No }\end{array}$} & \multirow{2}{*}{$\begin{array}{c}\text { Bukaan } \\
(\mathbf{m m})\end{array}$} & \multicolumn{2}{c}{$\begin{array}{c}\text { Spek. } \\
\text { Gradasi }\end{array}$} & $\begin{array}{c}\% \\
\text { Lolos }\end{array}$ & $\begin{array}{c}\text { \% } \\
\text { Tertahan }\end{array}$ & $\begin{array}{c}\text { Berat } \\
\text { Tertahan } \\
(\text { gram })\end{array}$ \\
\hline $3 / 4$ & 19 & 100 & 100 & 100 & 0 & 0 \\
\hline $1 / 2$ & 12,5 & 90 & 100 & 95 & 5 & 60 \\
\hline $3 / 8$ & 9,5 & 77 & 90 & 83,5 & 11,5 & 138 \\
\hline$\# 4$ & 4,75 & 53 & 69 & 61 & 22,5 & 270 \\
\hline$\# 8$ & 2,36 & 33 & 53 & 43 & 18 & 216 \\
\hline$\# 16$ & 1,18 & 21 & 40 & 30,5 & 12,5 & 150 \\
\hline$\# 30$ & 0,6 & 14 & 30 & 22 & 8,5 & 102 \\
\hline$\# 50$ & 0,3 & 9 & 22 & 15,5 & 6,5 & 78 \\
\hline$\# 100$ & 0,15 & 6 & 15 & 10,5 & 5 & 60 \\
\hline$\# 200$ & 0,075 & 4 & 9 & 6,5 & 4 & 48 \\
\hline PAN & - & 0 & 0 & 0 & 6,5 & 78 \\
\hline & & & & Total & 100 & 1200 \\
\hline
\end{tabular}


Cara menentukan komposisi agregat padaCampuran HRS adalah sebagai berikut :

No. $3 / 4,=0,00 \%=(0,00 / 100) \times 1200=0,00 \quad$ gram No. $1 / 2,=5,00 \%=(5,00 / 100) \times 1200=60,00$ gram No. $3 / 8^{\prime}=11,50 \%=(11,50 / 100) \times 1200=180,00$ gram Hasil perhitungan lainnya dapat dilihat pada Tabel 11 .

\subsection{Perencanaan Campuran Beton Aspal Lapis Aus (AC- $W C)$}

Dari hasil hitungan (Tabel 12, Tabel 13 dan Gambar 3) perkiraan kadar aspal optimum (PKAO) diperoleh nilai PKAO 5,5\%. Pada penelitian ini dibuat 6 variasi kadar aspal, kadar aspal yang digunakan berkisar antara 4,5\% $7,0 \%$ dengan interval $0,5 \%$ maka diperoleh kadar aspal $4,5 \%, 5,0 \%, 5,5 \%, 6,0 \%, 6,5 \%, 7,0 \%$.

Tabel 12. Hasil Pengujian Marshall Pada Kondisi PKAO - Kondisi Standar

\begin{tabular}{|c|c|c|c|c|c|c|c|c|}
\hline \multirow{2}{*}{$\begin{array}{c}\text { Karaktersitik } \\
\text { Campuran }\end{array}$} & \multirow{2}{*}{ Satuan } & \multicolumn{6}{|c|}{ Kadar Aspal (\%) } & \multirow{2}{*}{ Spek. } \\
\hline & & 4,5 & 5,0 & 5,5 & 6,0 & 6,5 & 7,0 & \\
\hline Kepadatan & $\mathrm{gr} / \mathrm{cm}^{3}$ & 2,232 & 2,253 & 2,253 & 2,270 & 2,284 & 2,274 & - \\
\hline VIM & $\%$ & 6,422 & 4,902 & 3,850 & 2,877 & 1,648 & 1,423 & $3,5-5$ \\
\hline VMA & $\%$ & 16,066 & 15,721 & 15,802 & 15,961 & 15,909 & 16,715 & Min. 15 \\
\hline VFB & $\%$ & 60,113 & 68,825 & 75,645 & 81,992 & 89,650 & 91,538 & Min. 65 \\
\hline Stabilitas & $\%$ & 1310,272 & 1525,878 & 1681,111 & 1325,776 & 1124,370 & 959,334 & Min. 800 \\
\hline Flow & $\mathrm{mm}$ & 4,777 & 4,260 & 4,363 & 4,673 & 5,433 & 5,997 & Min. 3 \\
\hline MQ & $\mathrm{kg} / \mathrm{mm}$ & 273,527 & 358,658 & 388,506 & 286,724 & 208,716 & 160,219 & Min. 250 \\
\hline
\end{tabular}

Tabel 13. Rekapitulasi hasil pengujian Marshall kondisi STOA, LTOA (5 Tahun) dan LTOA (10 Tahun)

\begin{tabular}{|c|c|c|c|c|c|c|c|}
\hline \multirow{2}{*}{$\begin{array}{l}\text { Karaktersitik } \\
\text { Campuran }\end{array}$} & \multirow{2}{*}{ Penuaan } & \multicolumn{6}{|c|}{ Kadar Aspal (\%) } \\
\hline & & 4,5 & 5,0 & 5,5 & 6,0 & 6,5 & 7,0 \\
\hline \multirow{3}{*}{ Kepadatan } & Kondisi STOA & 2,168 & 2,183 & 2,222 & 2,225 & 2,233 & 2,252 \\
\hline & LTOA (5 tahun) & 2,152 & 2,170 & 2,187 & 2,206 & 2,210 & 2,217 \\
\hline & LTOA (10 tahun) & 2,146 & 2,151 & 2,185 & 2,198 & 2,213 & 2,216 \\
\hline \multirow{3}{*}{ VIM } & Kondisi STOA & 9,123 & 7,873 & 5,572 & 4,820 & 3,864 & 2,390 \\
\hline & LTOA (5 tahun) & 9,780 & 8,404 & 7,056 & 5,620 & 4,846 & 3,912 \\
\hline & LTOA (10 tahun) & 10,018 & 9,203 & 7,133 & 5,996 & 4,699 & 3,959 \\
\hline \multirow{3}{*}{ VMA } & Kondisi STOA & 18,489 & 18,353 & 17,311 & 17,643 & 17,803 & 17,533 \\
\hline & LTOA (5 tahun) & 19,079 & 18,824 & 18,610 & 18,335 & 18,643 & 18,818 \\
\hline & LTOA (10 tahun) & 10,292 & 19,532 & 18,677 & 18,660 & 18,517 & 18,859 \\
\hline \multirow{3}{*}{ VFB } & Kondisi STOA & 50,659 & 57,143 & 67,884 & 72,690 & 78,444 & 86,405 \\
\hline & LTOA (5 tahun) & 48,741 & 55,421 & 62,088 & 69,350 & 74,057 & 79,240 \\
\hline & LTOA (10 tahun) & 48,072 & 52,894 & 61,810 & 67,870 & 74,624 & 79,041 \\
\hline \multirow{3}{*}{ Stabilitas } & Kondisi STOA & 1134,098 & 1362,997 & 1295,229 & 1139,181 & 1081,843 & 984,777 \\
\hline & LTOA (5 tahun) & 1055,392 & 1145,556 & 1238,474 & 1039,925 & 966,952 & 960,815 \\
\hline & LTOA (10 tahun) & 1019,083 & 1130,880 & 1178,226 & 1210,663 & 989,484 & 933.503 \\
\hline \multirow{3}{*}{ Flow } & Kondisi STOA & 4,413 & 3,960 & 4,637 & 4,593 & 4,864 & 5,893 \\
\hline & LTOA (5 tahun) & 3,980 & 3,157 & 3,347 & 3,943 & 4,397 & 4,167 \\
\hline & LTOA (10 tahun) & 3,393 & 3,203 & 3,120 & 3,340 & 3,687 & 4,667 \\
\hline \multirow{3}{*}{ MQ } & Kondisi STOA & 258,729 & 346,338 & 281,798 & 249,709 & 228,912 & 167,257 \\
\hline & LTOA (5 tahun) & 271,901 & 373,274 & 380,738 & 268,516 & 229,309 & 235,332 \\
\hline & LTOA (10 tahun) & 303,749 & 367,725 & 381,891 & 363,519 & 269,618 & 200,692 \\
\hline
\end{tabular}

\subsection{Pengaruh Proses Penuaan Terhadap Karakteristik Campuran Aspal Beton Lapis Aus (AC - WC)}

a. Kepadatan - Penuaan Aspal
Berdasarkan Gambar 4 dapat diketahui nilai kepadatan maksimum pada kondisi standar terjadi pada kadar aspal $6,5 \%$. Sedangkan pada kondisi penuaan baik penuaan 
STOA maupun LTOA 5 tahun dan LTOA 10 tahun nilai kepadatan mengalami kenaikan seiring bertambahnya kadar aspal dan belum terjadi kepadatan maksimum. Sehingga untuk memperoleh nilai kepadatan maksimum pada kondisi penuaan diperlukan kadar aspal yang lebih besar.

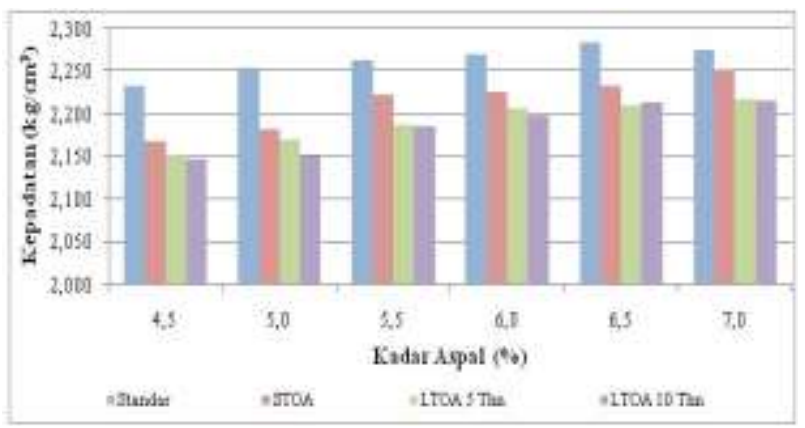

Gambar 4. Hubungan kepadatan terhadap kadar aspal pada kondisi standar dan kondisi penuaan.

Semakin lama proses penuaan mengakibatkan kepadatan campuran cenderung menurun. Hal ini dikarenakan penuaan mengakibatkan aspal menjadi keras sehingga aspal sebagai bahan pengisi rongga tidak mampu lagi untuk mengisi rongga dalam campuran. Untuk mendapat nilai kepadatan yang sama pada kondisi standar kadar aspal 4,5\% dengan jumlah tumbukan dan energi pemadatan yang sama, untuk aspal yang mengalami penuaan STOA dibutuhkan kadar aspal $6,5 \%$. Dalam hal ini penuaan dapat diperlambat dengan menambahkan kadar aspal.

b. Void In Mixture (VIM) - Penuaan Aspal

Berdasarkan Gambar 5 dapat diketahui nilai VIM akan semakin kecil bila kadar aspal semakin besar. Pada kondisi standar nilai VIM yang memenuhi spesifikasi yaitu pada kadar aspal $5,0 \%$ - 5,5\%, pada penuaan STOA yaitu pada kadar aspal 6,0\% - 6,5\% sedangkan pada penuaan LTOA yaitu pada kadar aspal 6,5\% $7,0 \%$.

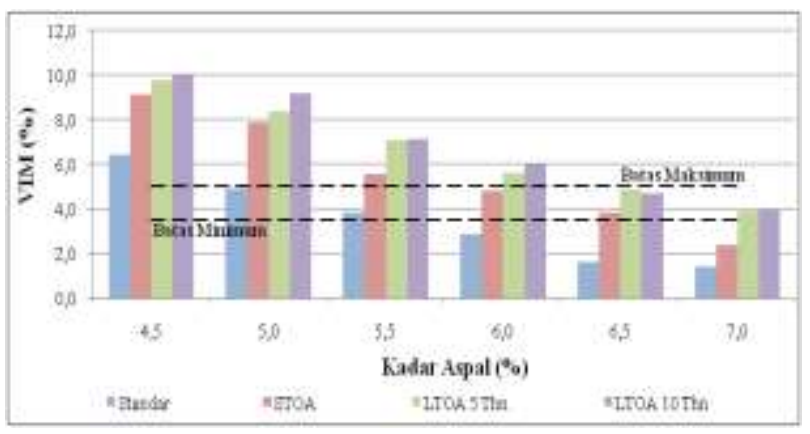

Gambar 5. Hubungan VIM terhadap kadar aspal pada kondisi standar dan kondisi penuaan.

Nilai VIM cenderung meningkat bila terjadi penuaan pada aspal yaitu penuaan STOA, LTOA 5 tahun dan LTOA 10 tahun. Karena aspal yang sudah mengalami penuaan akan bersifat lebih keras (flownya menjadi kecil) sehingga kemampuan aspal untuk mengisi rongga menjadi berkurang. c. Void in Mineral Agregat (VMA) - Penuaan Aspal

Berdasarkan Gambar 6 dapat diketahui nilai VMA akan cenderung semakin besar bila aspal mengalami penuaan karena aspal yang mengalami penuaan akan menjadi keras dan getas sehingga kemampuan aspal mengisi rongga antara agregat menjadi berkurang yang mengakibatkan campuran mengalami penurunan durabilitas hal ini sejalan dengan menurunya nilai VFB dan nilai VIM yang semakin naik.

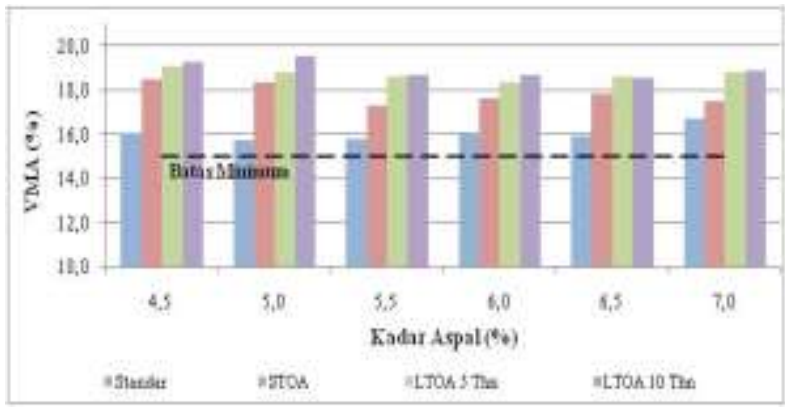

Gambar 6. Hubungan VMA terhadap kadar aspal pada kondisi standar dan kondisi penuaan.

Semakin bertambah kadar aspal kenaikan nilai VMA akibat penuaan semakin kecil. Hal ini membuktikan penuaan dapat diperlambat dengan penambahan kadar aspal.

d. Void Filled With Bitumen (VFB) - Penuaan Aspal

Berdasarkan Gambar 7 dapat diketahui nilai VFB akan semakin besar jika kadar aspal semakin bertambah. Nilai VFB yang memenuhi spesifikasi pada kondisi standar yaitu pada kadar aspal 5,5\% - 7,0\%, pada penuaan STOA yaitu pada kadar aspal 5,5\% - 7,0\% dan pada penuaan LTOA yaitu pada kadar aspal 6,0\% $7,0 \%$.

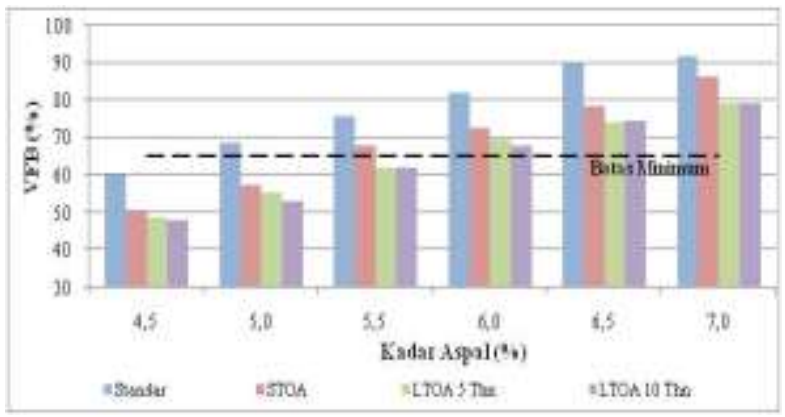

Gambar 7. Hubungan VFB terhadap kadar aspal pada kondisi standar dan kondisi penuaan.

Aspal yang mengalami penuaan membuat nilai VFB cenderung menurun karena penuaan mengakibatkan aspal menjadi keras sehingga kemampuan aspal untuk mengisi rongga menjadi berkurang selain itu fungsi aspal sebagai bahan pengikat antar agregat juga menjadi berkurang.

e. Stabilitas - Penuaan Aspal

Berdasarkan Gambar 8 dapat diketahui terjadi penurunan nilai stabilitas seiring lamanya penuaan tetapi masih sesuai dengan persyaratan spesifikasi yaitu 
minimum $800 \mathrm{~kg}$. Hal ini dipengaruhi oleh proses aging yang menyebabkan agregat dan aspal mengalami penguapan yang tinggi. Penguapan yang terjadi pada aspal mengakibatkan aspal menjadi lebih keras dan getas. Bila pemadatan campuran aspal dilakukan dengan kondisi campuran dalam keadaan getas maka pemadatan yang diberikan akan merusak bahkan menghancurkan campuran tersebut. Hal ini disebabkan karena pada campuran beraspal yang sudah cukup kaku, agregat pembentuknya sudah terikat kuat oleh aspal dan aspalnya tidak lagi berfungsi sebagai pelumas, sehingga energi pemadatan yang diberikan sudah tidak mampu lagi memaksa partikel agregat untuk bergerak mendekat satu dengan yang lainnya tetapi energi ini justru akan menghancurkan ikatan antara agregat dengan aspal yang sudah dibentuk sebelumnya.

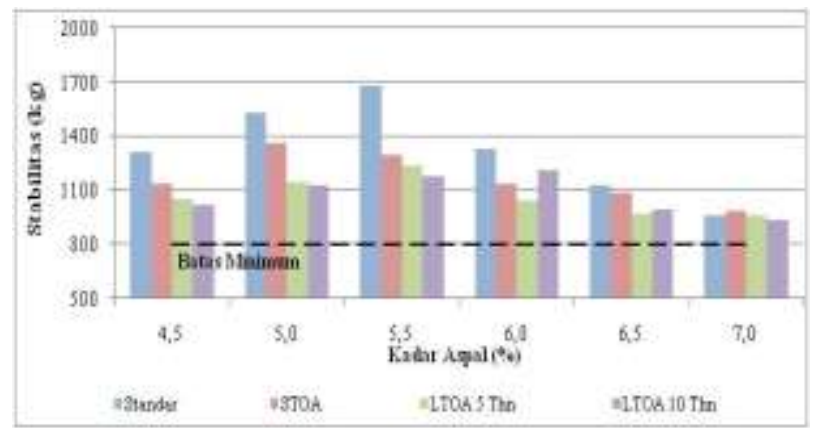

Gambar 8. Hubungan stabilitas terhadap kadar aspal pada kondisi standar dan kondisi penuaan.

Penurunan nilai stabilitas akibat penuaan begitu besar pada kadar aspal 4,5\% - 6,0\% tetapi pada kadar aspal $6,5 \%-7,0 \%$ penurunan nilai stabilitas akibat penuaan cenderung kecil. Sehingga dapat disimpulkan penuaan dapat diperlambat dengan penambahan kadar aspal.

f. Flow - Penuaan Aspal

Berdasarkan Gambar 9 dapat diketahui kelelehan campuran semakin menurun seiring lamanya waktu penuaan. Hal ini dikarenakan aspal yang mengalami penuaan akan menjadi keras sehingga kemampuan aspal sebagai bahan pengisi rongga tidak berfungsi dengan baik yang mengakibatkan rongga dalam campuran semakin besar dan kepadatan menjadi menurun.

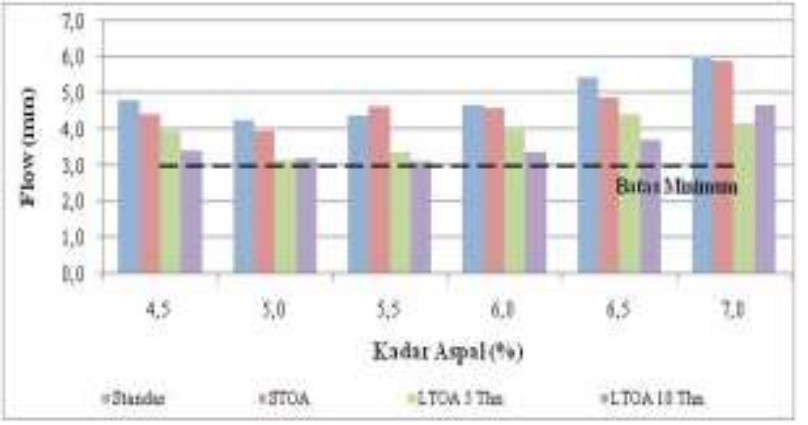

Gambar 9. Hubungan flow terhadap kadar aspal pada kondisi standar dan kondisi penuaan.

Nilai flow mengalami penurunan pada kadar aspal 4,5\% - 5,0\% dan terjadi kenaikan pada kadar aspal 5,5\% -
7,0\%. Berdasarkan spesifikasi nilai flow pada kondisi standar dan kondisi penuaan memenuhi spesifikasi minimum $3 \mathrm{~mm}$.

\section{g. Marshall Quotient (MQ) - Penuaan Aspal}

Berdasarkan Gambar 10 dapat diketahui bahwa nilai MQ pada kondisi standar, kondisi penuaan STOA dan penuaan LTOA 5 tahun yang memenuhi spesifikasi berada pada kadar aspal 4,5\% - 6,0\%, sedangkan pada penuaan LTOA masa layanan 10 tahun nilai MQ yang memenuhi spesifikasi berada pada kadar aspal 4,5\% $6,5 \%$.

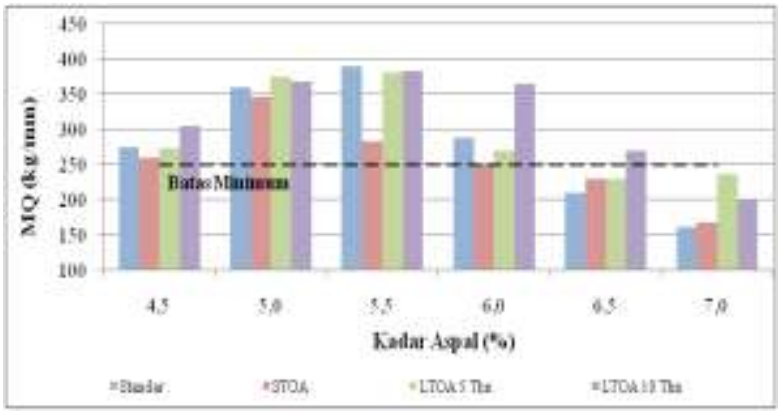

Gambar 10. Hubungan $M Q$ terhadap kadar aspal pada kondisi standar dan kondisi penuaan.

Dengan adanya penuaan maka perkerasan akan cenderung lebih kaku dilihat pada penuaan LTOA nilai MQ mengalami kenaikan dari kondisi standar, hal ini dikarenakan proses pengovenan selama $2-5$ hari yang menyebabkan penguapan / oksidasi pada campuran aspal sehingga daya lekat aspal dengan agregat menurun yang mengakibatkan campuran mengalami penurunan fleksibilitas yang dibuktikan dengan menurunnya nilai stabilitas dan flow.

\section{Kesimpulan}

Berdasarkan hasil pembahasan, dapat ditarik kesimpulan bahwa penuaan aspal baik kondisi STOA, LTOA 5 tahun dan LTOA 10 tahun telah mempengaruhi karakteristik campuran beton aspal lapis aus $(A C-W C)$. Penuaan aspal yang terjadi mengakibatkan nilai kepadatan, VFB, stabilitas dan flow mengalami penurunan. Penurunan yang terjadi akan semakin besar seiring lamanya umur penuaan. Sedangkan pada nilai VIM, VMA dan MQ, teradi kenaikan seiring lama proses penuaan. Kenaikan dan penurunan nilai karakteristik campuran tersebut mengalami perubahan yang kecil seiring bertambahnya kadar aspal.

Berdasarkan hasil dari penelitian dan pengalaman yang didapatkan selama proses penelitian, maka untuk penelitian yang selanjutnya dapat diberikan saran - saran sebagai berikut :

1) Perlu dilakukan penelitian lebih lanjut pengaruh penuaan aspal pada karakteristik campuran beton aspal lapis aus $(\mathrm{AC}-\mathrm{WC})$ dengan menggunakan kadar aspal yang lebih tinggi dari 7,0\%.

2) Perlu dilakukan penelitian lebih lanjut pengaruh penuaan aspal pada karakteristik campuran beton aspal yang lain.

3) Perlu dilakukan penelitian lebih lanjut pengaruh penuaan aspal pada karakteristik aspal itu sendiri. 


\section{Daftar Pustaka}

[1] Anonim, Spesifikasi Umum Edisi 2010. Direktorat Jenderal Bina Marga Departemen Pekerjaan Umum. Jakarta.http://binamarga2010.blogspot.co.id/2016/09 /spesifikasi-umum2010.html (diakses pada 23 Maret 2018).

[2] R. Anwar Yamin, and Herman, "Pengaruh Lingkungan Tropis Indonesia Pada Penuaan Aspal dan Modulus Kekakuan Resilien Campuran Beraspal”, Jurnal Transportasi, vol. 5, no. 2, p. 99, 2005.

[3] E. Ngii, "Meningkatkan Durabilitas Campuran Beton Aspal Yang Mengalami Proses Penuaan Aspal Saat Konstruksi (Short Term) Dengan Teknik Penambahan Kadar Aspal”, Stabilita: Jurnal Ilmiah Teknik Sipil, vol. 1, no. 2, p. $101,2013$.

[4] Mashuri, F. Astuti, and J.F. Batti, "Penuaan Dini dan Durabilitas Perkerasan Lapis Tipis Beton Aspal Lapis Aus (Hrs-Wc) Yang Menggunakan ROADCEL-50", Jurnal Teknik Sipil Infrastruktur, vol. 4, no. 2, p. 103 $-, 2014$.

[5] I. Haryanto, "Pengaruh Penuaan Terhadap Kuat Geser Langsung Campuran Beraspal”, Jurnal Transportasi, vol. 4, no. 2, p. 131, 2004.

[6] Mashuri, R. Rahman, and H. Basri, "Studi Pengaruh Penambahan ROADCEL-50 Terhadap Karakteristik Campuran Lapis Tipis Beton Aspal (HRS-WC)", Jurnal Rekayasa dan Manajemen Transportasi, vol.1, no.1, p. 1, 2011.

[7] T.D. Septiawan, "Pengaruh Penggunaan Bahan Tambah Serbuk Karet Ban Pada Campuran Lapis Aspal Beton”, Jurnal Rekayasa Sipil, vol.1, no.1, p. 9, 2013.
[8] Damraeni, Pengaruh Proses Penuaan Bahan Pengikat Mengandung Aspal Alam Terhadap Karakteristik Campuran Bergradasi Senjang (Tugas Akhir) Palu: Universitas Tadulako, 2009.

[9] Irfan, Pengaruh Penggunaan Bahan Tambah Sulfur Terhadap Penuaan Campuran Asphaltic Concrete wearing Course (AC-WC) (Tugas Akhir). Palu: Universitas Tadulako, 2012.

[10] H. Saodang, Konstruksi Jalan Raya, Bandung: Nova, 2010.

[11] Sugiyono, Metode Penelitian Kuantitatif Kualitatif dan R\&D. Bandung: Alfabeta, 2017.

[12] S. Sukirman, Perkerasan Lentur Jalan Raya, Bandung: Nova, 1999.

[13] S. Sukirman, Perkerasan Lentur Jalan Raya, Bandung: Nova, 2003.

[14] T. Supriadi, Syarifudin, dan H. Azwansyah, "Perkerasaan Campuran Aspal AC - WC Terhadap Sifat Penuaan Aspal ", Jurnal Mahasiswa Teknik Sipil, vol. 5 no. 2, p. $1,2018$.

[15] S. Widodo, S.R. Harnaeni, and E. Wijayanti, "Pengaruh Penuaan Aspal Terhadap Karakteristik Asphalt Concrete Wearing Course", Seminar Nasional Teknik Sipil UMS, p. 50, 2012. 
This page is intentionally left blank 